\title{
Hexaazide octahedral molybdenum cluster complexes: synthesis, properties and the evidence of hydrolysis
}

\author{
Yuri A. Vorotnikov ${ }^{\mathrm{a}}$, Olga A. Efremova*b, Igor N. Novozhilova, Vadim V. Yanshole ${ }^{\mathrm{c}, \mathrm{d}}$, \\ Natalia V. Kuratievaa,d, Konstantin A. Brylev ${ }^{\mathrm{a}, \mathrm{d}}$, Noboru Kitamura ${ }^{\mathrm{e}}$, Yuri V. Mironova,d, \\ Michael A. Shestopalov ${ }^{*}, \mathrm{a}, \mathrm{f}$ \\ ${ }^{a}$ Nikolaev Institute of Inorganic Chemistry SB RAS, 3 Acad. Lavrentiev Ave., 630090 Novosibirsk, \\ Russian Federation \\ ${ }^{b}$ Department of Chemistry, University of Hull, Cottingham Road, Hull, HU6 7RX \\ 'International Tomography Center SB RAS, 3a Institutskaya st., 630090 Novosibirsk, Russian Federation \\ ${ }^{d}$ Novosibirsk State University, 2 Pirogova Str., 630090 Novosibirsk, Russian Federation \\ ${ }^{e}$ Department of Chemistry, Faculty of Science, Hokkaido University, 060-0810 Sapporo, Japan

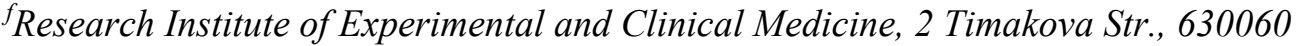 \\ Novosibirsk, Russian Federation
}

\begin{abstract}
This article reports the synthesis, crystal structure of new molybdenum hexaazide cluster complex $\left({ }^{\mathrm{n}} \mathrm{Bu}_{4} \mathrm{~N}\right)_{2}\left[\left\{\mathrm{Mo}_{6} \mathrm{I}_{8}\right\}\left(\mathrm{N}_{3}\right)_{6}\right](3)$ and comparison of its photophysical and electrochemical properties to those of earlier reported analogues $\left({ }^{\mathrm{n}} \mathrm{Bu}_{4} \mathrm{~N}\right)_{2}\left[\left\{\mathrm{M}_{6} \mathrm{X}_{8}\right\}\left(\mathrm{N}_{3}\right)_{6}\right](\mathrm{X}=\mathrm{Cl}, \mathrm{Br})$. Additionally, the dimerisation of $\mathbf{3}$ as a result of hydrolysis was revealed by mass spectrometry and single crystal X-Ray diffraction. Indeed, the structurally characterised compound $\left({ }^{\mathrm{n}} \mathrm{Bu}_{4} \mathrm{~N}\right)_{4}\left[\left(\left\{\mathrm{Mo}_{6} \mathrm{I}_{8}\right\}\left(\mathrm{N}_{3}\right)_{5}\right)_{2} \mathrm{O}\right]$ represents the first example of oxobridged dimer of octahedral molybdenum clusters complexes.
\end{abstract}

Key words: octahedral molybdenum clusters, crystal structure, luminescence, hydrolysis, ESI mass spectrometry

\section{Introduction}

Octahedral molybdenum cluster complexes with general formula $\left[\left\{\mathrm{Mo}_{6} \mathrm{X}_{8}\right\} \mathrm{L}_{6}\right]^{\mathrm{n}}$ exhibit outstanding photoluminescence properties such as bright emission in the red/near IR region with high quantum yields up to 0.65 and luminescence lifetimes up to $\sim 400 \mu \mathrm{s}$.[1-6] It is also wellknown that these clusters act as efficient photosensitisers in the processes associated with generation of singlet oxygen $\left({ }^{1} \mathrm{O}_{2}\right) \cdot[7-10]$ Due to these photophysical properties hexamolybdenum cluster complexes are of special interest in the fields of medicine as therapeutic and theranostic agents (e.g. as imaging and photodynamic therapeutic agents) [11] and biology as bioimaging and biolabeling agents.[12-15]

Unlike the related photoluminescent hexarhenium cluster complexes [16-20], the major "bottleneck" issue that hinders the direct application of the hexamolybdenum clusters in biomedical applications is poor solubility in water of the majority of known cluster complexes. To explore the great potential of the octahedral molybdenum cluster complexes in biomedical applications, research so far was mostly focused on the development of the hybrid materials based on inert inorganic [8, 21, 22] or organic [23-27] matrices. This approach typically uses organic soluble metal cluster precursors as either $\mathrm{Cs}^{+}$or ${ }^{\mathrm{n}} \mathrm{Bu}_{4} \mathrm{~N}^{+}$salts to irreversibly immobilise them within the matrix due to easy substitution of terminal ligands. The poor solubility issue was recently resolved by Kirakci et al. [28] via the development of water soluble complexes $\mathrm{Na}_{2}\left[\left\{\mathrm{Mo}_{6} \mathrm{I}_{8}\right\} \mathrm{L}_{6}\right]$ (where $\mathrm{L}_{\text {is }} \mathrm{N}_{3}{ }^{-}$or $\mathrm{NCS}^{-}$). However, the hydrolysis of these complexes in an aqueous solution was observed. Additionally, the interest to hexaazide molybdenum cluster complexes is also associated with their potential in so called azide-alkyne click reactions, which could allow further functionalisation of the cluster complexes. Indeed, Knott et al. demonstrated that octahedral rhenium clusters with terminal azide ligands can be used in such type of 
cycloaddition reactions.[29] Moreover such azido-Mo6 cluster complexes were shown to exhibit photocatalytic activity.[30, 31]

Therefore, in the present work we report the synthesis and the crystal structure of organic soluble ${ }^{n} \mathrm{Bu}_{4} \mathrm{~N}^{+}$salt of $\left[\left\{\mathrm{Mo}_{6} \mathrm{I}_{8}\right\}\left(\mathrm{N}_{3}\right)_{6}\right]^{2-}$ and its photophysical and electrochemical properties in comparison with those of related compounds $\left({ }^{\mathrm{n}} \mathrm{Bu} 4 \mathrm{~N}\right)_{2}\left[\left\{\mathrm{Mo}_{6} \mathrm{Cl}_{8}\right\}\left(\mathrm{N}_{3}\right)_{6}\right]$ (1) and $\left({ }^{\mathrm{n} B u_{4} N}\right)_{2}\left[\left\{\mathrm{Mo}_{6} \mathrm{Br}_{8}\right\}\left(\mathrm{N}_{3}\right)_{6}\right]$ (2). Moreover, we also investigated the hydrolysis of $\left({ }^{\mathrm{n}} \mathrm{Bu} 4 \mathrm{~N}\right)_{2}\left[\left\{\mathrm{Mo}_{6} \mathrm{I}_{8}\right\}\left(\mathrm{N}_{3}\right)_{6}\right](3)$ in an acetone solution and determined the crystal structure of the product of hydrolysis - the first of its kind $\mathrm{Mo}_{6}$ based dimer compound $\left({ }^{\mathrm{n}} \mathrm{Bu}_{4} \mathrm{~N}\right)_{4}\left[\left(\left\{\mathrm{Mo}_{6} \mathrm{I}_{8}\right\}\left(\mathrm{N}_{3}\right)_{5}\right)_{2} \mathrm{O}\right](4)$.

\section{Experimental section}

\section{Materials}

All reagents and solvents employed were commercially available and used as received without further purification. $\left({ }^{\mathrm{n}} \mathrm{Bu} 4 \mathrm{~N}\right)_{2}\left[\left\{\mathrm{Mo}_{6} \mathrm{I}_{8}\right\}\left(\mathrm{NO}_{3}\right)_{6}\right]$ was prepared according to the earlier described procedure.[27] $\left({ }^{\mathrm{n}} \mathrm{Bu} 4 \mathrm{~N}\right)_{2}\left[\left\{\mathrm{Mo}_{6} \mathrm{X}_{8}\right\}\left(\mathrm{N}_{3}\right)_{6}\right](\mathrm{X}=\mathrm{Cl}(\mathbf{1})$ and $\mathrm{Br}(2))$ were prepared as described in [32].

\section{Instrumentation}

Elemental analysis was carried out on EuroVector EA3000 Elemental Analyser. FTIR was recorded on Bruker Vertex 80 in $\mathrm{KBr}$ pellet.

\section{Synthesis of $\left({ }^{{ }^{B} \mathrm{Bu}_{4} \mathrm{~N}}\right)_{2}\left[\left\{\mathrm{Mo}_{6} \mathrm{I}_{8}\right\}\left(\mathrm{N}_{3}\right)_{6}\right](3)$}

$500 \mathrm{mg}(0.20 \mathrm{mmol})$ of $\left({ }^{\mathrm{n}} \mathrm{Bu}_{4} \mathrm{~N}\right)_{2}\left[\left\{\mathrm{Mo}_{6} \mathrm{I}_{8}\right\}\left(\mathrm{NO}_{3}\right)_{6}\right]$ and $239 \mathrm{mg}(3.68 \mathrm{mmol})$ of $\mathrm{NaN}_{3}$ were dissolved in $50 \mathrm{~mL}$ of acetone. The mixture was heated at $55^{\circ} \mathrm{C}$ for $18 \mathrm{~h}$. Red solution containing the product was isolated from the deep red precipitate by centrifugation. The solvent was removed on a rotary evaporator and the product was redissolved in $3 \mathrm{~mL}$ of acetone. The bulk product was isolated from the solution by the addition of an excess amount of diethyl ether followed by centrifugation and then was dried in air. Yield: $332 \mathrm{mg}(70 \%)$. Anal. calcd for $\mathrm{C}_{32} \mathrm{H}_{72} \mathrm{I}_{8} \mathrm{Mo}_{6} \mathrm{~N}_{20}$ : C 16.5, H 3.1 N 12.0; found C 16.2, H 3.0, N 11.9. Single crystals of 3 suitable for X-ray diffraction analysis were obtained by slow diffusion of diethyl ether in an acetone solution of the complex. FTIR $\left(\mathrm{KBr}, \mathrm{cm}^{-1}\right): v_{\mathrm{as}}\left(\mathrm{N}_{3}\right)-2046 ; v_{\mathrm{s}}\left(\mathrm{N}_{3}\right)-1330 ; \sigma\left(\mathrm{N}_{3}\right)-634$.

\section{Photoluminescence measurements}

For photoluminescence measurements of 1-3, powdered samples of the complexes were placed between two non-fluorescent glass plates. The absorbance of acetonitrile solutions was set at $<0.1$ at $355 \mathrm{~nm}$. The solutions were poured into quartz cuvettes. To deaerate, the solutions were purged with an Ar-gas stream for $30 \mathrm{~min}$ and then the cuvettes were sealed. Measurements were carried out at $298 \mathrm{~K}$. The samples were excited by $355-\mathrm{nm}$ laser pulses ( 6 ns duration, LOTIS TII, LS2137/3). Corrected emission spectra were recorded on a red-light-sensitive multichannel photodetector (Hamamatsu Photonics, PMA-11). For emission decay measurements, the emission was analysed using a streakscope system (Hamamatsu Photonics, C4334 and C5094). The emission quantum yields were determined using an Absolute Photo-Luminescence Quantum Yield Measurement System (Hamamatsu Photonics, C9920-03), which comprised a xenon excitation light source (the excitation wavelength was set at $400 \mathrm{~nm}$ ), an integrating sphere, and a redsensitive multichannel photodetector (Hamamatsu Photonics, PMA-12).

\section{Mass spectrometry}

The mass spectrometric (MS) detection was performed with a direct injection of liquid samples via automatic syringe pump KDS 100 (KD scientific, USA) at $180 \mu \mathrm{L} / \mathrm{h}$ rate on an electrospray 
ionisation quadrupole time-of-filght (ESI-q-TOF) high-resolution mass spectrometer Maxis 4G (Bruker Daltonics, Germany). Mass spectra were recorded in negative mode within $700-4500 \mathrm{~m} / \mathrm{z}$ range. The instrument parameters were the following: end plate offset $500 \mathrm{~V}$; capillary voltage $+2800 \mathrm{~V}$ for negative mode; nebulizer pressure 1 bar; dry gas flow $4 \mathrm{~L} / \mathrm{min}$; dry gas temperature $180^{\circ} \mathrm{C}$. The MS calibration was performed externally using ESI-L calibration mix (Agilent, USA); typical resolution was $c a$. 50000, accuracy $<1 \mathrm{ppm}$.

\section{Cyclic voltammetry}

Cyclic voltammetry (CV) was performed using a Metrohm 797 VA Computrace instrument with a glassy carbon electrode as the working electrode and a saturated silver / silver chloride $(\mathrm{Ag} / \mathrm{AgCl})$ in $3.5 \mathrm{M} \mathrm{KCl}$ and platinum electrode as the auxiliary electrode. A $0.15 \mathrm{M}$ solution of tetra-n-butylammonium perchlorate in acetonitrile was used as an electrolyte. Solutions of the samples in the electrolyte (1-2 $\mathrm{mM})$ were degassed by purging with argon prior to recording the CV measurements.

\section{Crystal structure determination}

Crystals of $\mathbf{3}$ appropriate for single crystal X-ray analysis were obtained by slow diffusion of diethyl ether vapours into acetone solution. Several crystals of compound $\left({ }^{\mathrm{n}} \mathrm{Bu} 4 \mathrm{~N}\right)_{4}\left[\left(\left\{\mathrm{Mo}_{6} \mathrm{I}_{8}\right\}\left(\mathrm{N}_{3}\right)_{5}\right)_{2} \mathrm{O}\right]$ (4) were also found as a minor by-product and structurally characterised. Single-crystal X-ray diffraction data for $\mathbf{3}$ and $\mathbf{4}$ were collected using the graphite monochromatised Mo K $\alpha$-radiation $(\lambda=0.71073 \AA$ ) at 298(2) K on a Bruker Nonius X8 APEX diffractometer equipped with a $4 \mathrm{~K} \mathrm{CCD}$ area detector. The $\varphi$-scan technique was employed to measure intensities. Absorption corrections were applied empirically using the SADABS program [33]. Structures were solved by the direct methods of the difference Fourier synthesis and further refined by the full-matrix least squares method using the SHELXTL package [33]. Atomic thermal parameters for non-hydrogen atoms were refined anisotropically. The positions of hydrogen atoms of tetrabutylammonium cations were calculated corresponding to their geometrical conditions and refined using the rigid body approximation (riding model). Crystallographic data as well as details on data collection and refinement are given in Table 1.

Table 1. Crystallographic data for compounds 3-4.

\begin{tabular}{|c|c|c|}
\hline & 3 & 4 \\
\hline $\begin{array}{l}\text { Empirical formula } \\
\text { Formula wejght }\end{array}$ & $\begin{array}{c}\mathrm{C}_{32} \mathrm{H}_{72} \mathrm{I}_{8} \mathrm{Mo}_{6} \mathrm{~N}_{20} \\
2327.94\end{array}$ & $\begin{array}{c}\mathrm{C}_{64} \mathrm{H}_{144} \mathrm{I}_{16} \mathrm{Mo}_{12} \mathrm{~N}_{34} \mathrm{O} \\
458781\end{array}$ \\
\hline Crystal system & Monoclinic & Monoclinic \\
\hline Space group & $P 2_{1} / n$ & $C 2 / c$ \\
\hline$a, \AA$ & $14.6395(2)$ & $34.870(2)$ \\
\hline$b, \AA$ & $12.5483(2)$ & $14.1489(7)$ \\
\hline$c, \AA$ & $17.6439(3)$ & $25.013(1)$ \\
\hline$\beta,{ }^{\circ}$ & $97.442(1)$ & $103.273(1)$ \\
\hline$V, \AA^{3}$ & $3213.90(9)$ & $12011(1)$ \\
\hline$Z$ & 2 & 4 \\
\hline Calc. density, $\mathrm{g} \mathrm{cm}^{-3}$ & 2.406 & 2.537 \\
\hline$\mu, \mathrm{mm}^{-1}$ & 5.019 & 5.369 \\
\hline Crystal size, $\mathrm{mm}^{3}$ & $0.12 \times 0.10 \times 0.08$ & $0.15 \times 0.12 \times 0.08$ \\
\hline$\Theta$ range, ${ }^{\circ}$ & $2.35-27.54$ & $1.67-30.58$ \\
\hline & $-19 \leq \mathrm{h} \leq 18$ & $-48 \leq \mathrm{h} \leq 49$ \\
\hline Index ranges & $\begin{array}{l}-16 \leq \mathrm{k} \leq 15 \\
-22<1<22\end{array}$ & $\begin{array}{l}-20 \leq \mathrm{k} \leq 19 \\
-35<1<28\end{array}$ \\
\hline Reflections collected/ & $3021 \overline{9} / \overline{7} 363$ & $53228 / 18289$ \\
\hline independent $\left(R_{\text {int }}\right)$ & $(0.0401)$ & $(0.0323)$ \\
\hline Completeness, $\%$ & 99.9 & 99.9 \\
\hline
\end{tabular}




$\begin{array}{ccc}\text { Data / restraints / } & 7363 / 20 / 276 & 18289 / 0 / 581 \\ \text { parameters } & 1.098 & 1.088 \\ \text { Goodness-of-fit } & 0.0375,0.0965 & 0.0412,0.1001 \\ R_{1}, w R_{2}(I>2 \sigma(I)) & 0.0555,0.1032 & 0.0714,0.1116 \\ R_{1}, w R_{2} \text { (all data) } & 1.357,-1.168 & 3.666,-1.546 \\ \Delta \rho_{\max }, \Delta \rho_{\min }, e \AA^{-3} & & \end{array}$

\section{Results and discussion}

\section{Synthesis and structural characterisation}

The complex $\left[\left\{\mathrm{Mo}_{6} \mathrm{I}_{8}\right\}\left(\mathrm{N}_{3}\right)_{6}\right]^{2-}$ was synthesised by the substitution of labile $\mathrm{NO}_{3}{ }^{-}$ligands in $\left[\left\{\mathrm{Mo}_{6} \mathrm{I}_{8}\right\}\left(\mathrm{NO}_{3}\right)_{6}\right]^{2-}$ with $\mathrm{N}_{3}^{-}$under mild heating in acetone $\left(55^{\circ} \mathrm{C}\right)$ and crystallised as a salt of composition $\left({ }^{\mathrm{n}} \mathrm{Bu} 4 \mathrm{~N}\right)_{2}\left[\left\{\mathrm{Mo}_{6} \mathrm{I}_{8}\right\}\left(\mathrm{N}_{3}\right)_{6}\right]$ (3). The bulk deep red product $\mathbf{3}$ was obtained by the evaporation of the solvent under reduced pressure, while the crystals of $\mathbf{3}$ suitable for X-ray diffraction analysis were obtained by the slow diffusion of diethyl ether into an acetone solution within several days. Along with the crystals of $\mathbf{3}$, we also found few crystals of a minor by-product, namely, a unique dimeric compound $\mathbf{4}$. Indeed, the properties of the intriguing compound $\mathbf{4}$ are worthwhile studying. Unfortunately, our attempts to obtain an appreciable amount of $\mathbf{4}$ as a pure phase were so far not successful.

To evaluate the effect of the inner halogen ligands on the photophysical and electrochemical properties of hexaazide molybdenum cluster complexes, we have also synthesised the chloro- and bromo- analogues, $\left({ }^{\mathrm{n}} \mathrm{Bu} 4 \mathrm{~N}\right)_{2}\left[\left\{\mathrm{Mo}_{6} \mathrm{X}_{8}\right\}\left(\mathrm{N}_{3}\right)_{6}\right]$, where $\mathrm{X}$ is $\mathrm{Cl}(\mathbf{1})$ or $\mathrm{Br}(\mathbf{2})$, in the similar fashion, but at the room temperature.

Crystal structure of compound 3. A single crystal X-ray diffraction analysis revealed that compound 3 crystallises in monoclinic space group $P 2_{1} / n$, and it is isostructural to earlier reported cluster complexes 1 and 2.[32] Cluster compound $\mathbf{3}$ contains $\left\{\mathrm{Mo} 6 \mathrm{I}_{8}\right\}^{4+}$ cluster core with the centre of inversion (position $2 a$ ) being at its centre and consists of a Mo6 octahedron inscribed into a nearly perfect I 8 cube. Mo-Mo (2.6581(7)-2.6728(6) $\AA)$, Mo-I (2.7864(7)-2.7990(5) $\AA)$ distances are typical for Mo6 complexes, and their geometrical details do not differ significantly from the starting material and the related compounds (Table 2).[27, 32] All Mo atoms are coordinated by terminal $\mathrm{N}_{3}$-ligands in the mode similar to other hexa-azide cluster complexes (Figure 1).[32, 34, $35]$ Mo-N distances (2.143(5)-2.150(5) $\AA$ ) in compound 3 are slightly larger than those reported earlier for related compounds 1 and 2 (Table 2).

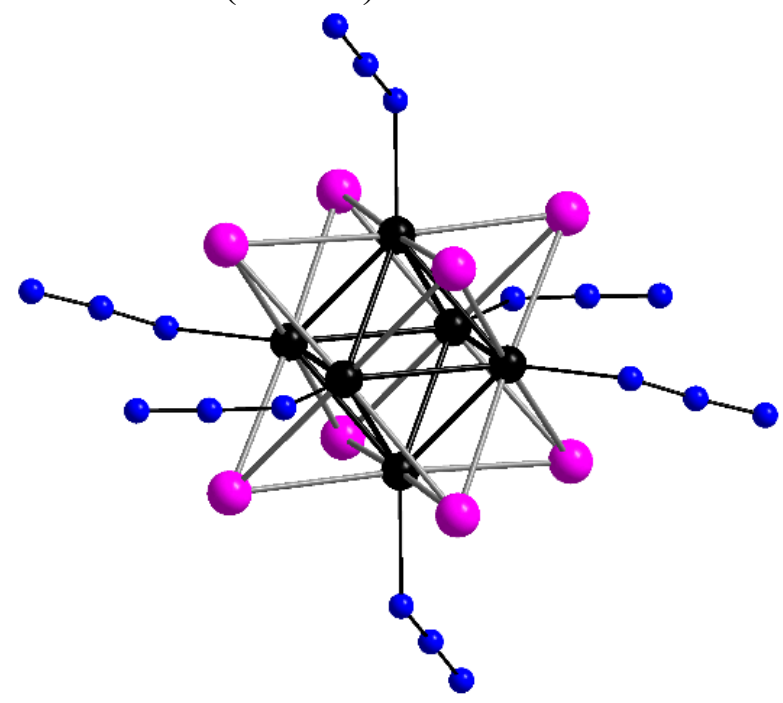

Figure 1. The structure of the cluster anion $\left[\left\{\mathrm{Mo}_{6} \mathrm{I}_{8}\right\}\left(\mathrm{N}_{3}\right)_{6}\right]^{2-}$ in the crystal structure of 3 .

Crystal structure of compound 4 . The product of hydrolysis of $\mathbf{3}$, compound $\mathbf{4}$, crystallises in the monoclinic space group $C 2 / c$ and consists of $\left[\left(\left\{\mathrm{Mo}_{6} \mathrm{I}_{8}\right\}\left(\mathrm{N}_{3}\right)_{5}\right)_{2} \mathrm{O}\right]^{4-}$ dimeric cluster anion and 
${ }^{n} \mathrm{Bu}_{4} \mathrm{~N}^{+}$counter ions. Anion $\left[\left(\left\{\mathrm{Mo}_{6} \mathrm{I}_{8}\right\}\left(\mathrm{N}_{3}\right)_{5}\right)_{2} \mathrm{O}\right]^{4-}$ represents a dimer of two cluster units ( $\left.\left\{\mathrm{Mo}_{6} \mathrm{I}_{8}\right\}\left(\mathrm{N}_{3}\right)_{5}\right)^{-}$linked together by a $\mu_{2}$-briging $\mathrm{O}^{2-}$ ligand (Figure 2 ) coordinated under almost a straight angle $\left(\mathrm{Mo}-\mathrm{O}-\mathrm{Mo}\right.$ angle is $\left.177.7^{\circ}\right)$. The centre of the dimer, the oxygen atom, is in the special position $4 e(0, \mathrm{y}, 1 / 4)$ with the overall $C_{2}$ point symmetry of the anion. The Mo-Mo, Mo-I and Mo-N distances and overall structure of the fragment $\left(\left\{\mathrm{Mo}_{6} \mathrm{I}_{8}\right\}\left(\mathrm{N}_{3}\right)_{5}\right)^{-}$is similar to those in the compound 3 (Table 2). To the best of our knowledge, this is the first structurally characterised example of a dimeric $\left\{\mathrm{Mo}_{6} \mathrm{X}_{8}\right\}$-linker- $\left\{\mathrm{Mo}_{6} \mathrm{X}_{8}\right\}$ cluster complex. Indeed, within the range of all octahedral transition metal cluster complexes, we found only one example of such a dimer, namely, compound $\left({ }^{n} \mathrm{Bu} 4 \mathrm{~N}\right)_{4}\left[\left(\left\{\mathrm{Re}_{6} \mathrm{~S}_{5} \mathrm{OCl}_{2}\right\} \mathrm{Cl}_{5}\right)_{2} \mathrm{O}\right]$. In this rhenium analogue cluster fragments $\left(\left\{\mathrm{Re}_{6} \mathrm{~S}_{5} \mathrm{OCl}_{2}\right\} \mathrm{Cl}_{5}\right)^{-}$are also linked by a bridging oxygen atom with coordination angle $\mathrm{Re}-\mathrm{O}-\mathrm{Re}$ being equal to $154.6^{\circ}$.[36] In classical coordination chemistry of molybdenum, however, the formation of poly-nuclear molybdenum complexes having Mo-O-Mo bond angles close to $180^{\circ}$ is not surprising. Indeed, such geometry was found in complexes $\left[\left(\mathrm{MoO}_{2}\right)_{2}\left(\mathrm{H}_{2} \mathrm{O}\right)_{2}(\mu-\mathrm{O})(\mathrm{BIMIPY}-\right.$ $\left.\left.\mathrm{H}^{+}\right)_{2}\right] \cdot 4 \mathrm{DMSO} \cdot 2 \mathrm{H}_{2} \mathrm{O}$ (where BIMIPY is 4-(1H-benzimidazol-2-yl)-5-(hydroxymethyl)-2methylpyridin-3-ol) [37], [Mo(TTP) $\left.\mathrm{Cl}_{2}\right] \mathrm{O}_{2} \cdot \mathrm{CH}_{2} \mathrm{Cl}_{2}$ (where TTP is 5,10,15,20-tetra- $p$-tolyl porphyrin) [38], and many other compounds.

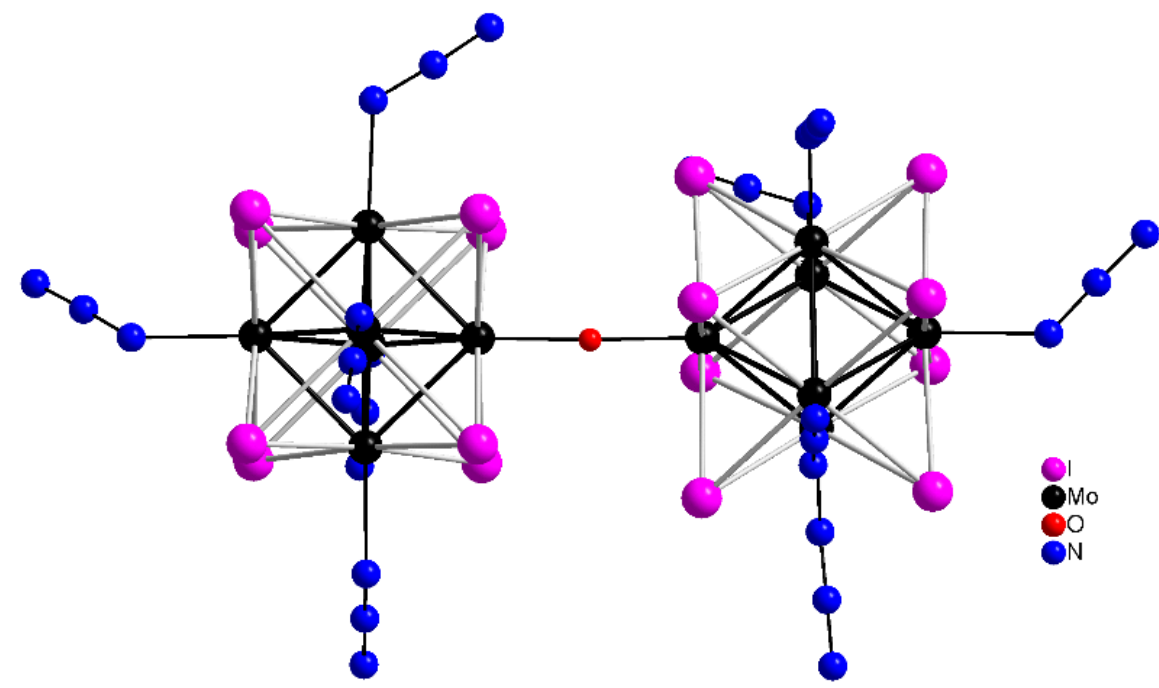

Figure 2. The structure of dimer cluster anion $\left[\left(\left\{\mathrm{Mo}_{6} \mathrm{I}_{8}\right\}\left(\mathrm{N}_{3}\right)_{5}\right)_{2} \mathrm{O}\right]^{4-}$ in the crystal structure 4.

Table 2. Selected interatomic distances $(\AA)$ and angles for 1-4.

\begin{tabular}{|c|c|c|c|c|}
\hline Compound & $\mathbf{1}[32]$ & $\mathbf{2}[32]$ & $\mathbf{3}$ & $\mathbf{4}$ \\
\hline Mo-Mo $(\AA)$ & $2.587(1)-2.601(1)$ & $2.617(2)-2.632(2)$ & $2.6581(7)-2.6728(6)$ & $2.6657(6)-2.6847(6)$ \\
\hline Mo-X $(\AA)$ & $2.455(3)-2.495(3)$ & $2.603(2)-2.614(2)$ & $2.7864(7)-2.7990(5)$ & $2.7833(6)-2.8166(5)$ \\
\hline Mo-N $(\AA)$ & $2.109(8)-2.125(8)$ & $2.09(2)-2.12(1)$ & $2.143(5)-2.150(5)$ & $2.128(5)-2.179(5)$ \\
\hline Mo-N-N $\left(^{\circ}\right)$ & $125.3(7)-131.3(8)$ & $124(1)-133(2)$ & $125.9(5)-131.8(6)$ & $123.1(4)-135.4(4)$ \\
\hline Mo-O $(\AA)$ & - & - & - & $1.9194(4)$ \\
\hline Mo-O-Mo $\left(^{\circ}\right)$ & - & - & - & $177.7(3)$ \\
\hline
\end{tabular}

\section{Photophysical properties}

Despite the fact that compounds $\mathbf{1}$ and $\mathbf{2}$ are known since 1997 from the work of Bublitz et al. [32], as well as their recently obtained analogue, the sodium salt of $\left[\mathrm{Mo}_{6} \mathrm{I}_{8}\left(\mathrm{~N}_{3}\right)_{6}\right]^{2-}$ [28], the photophysical properties of the cluster complexes $\left(\mathrm{Bu}_{4} \mathrm{~N}\right)_{2}\left[\left\{\mathrm{Mo}_{6} \mathrm{X}_{8}\right\}\left(\mathrm{N}_{3}\right)_{6}\right](\mathrm{X}=\mathrm{Cl}, \mathrm{Br}$ and $\mathrm{I})$ have not been reported. The absorption spectra of 1-3 are presented in Figure 3. With the increase of the weight of the cluster core the absorbance onset shifts slightly to the red region. This signifies some decrease of the optical energy gap of the cluster complexes, which is in agreement with studies of other related cluster complexes [23]. Luminescence properties of compounds 1-3 were 
investigated in the solid state and in aerated and deaerated acetonitrile solutions. The excitation spectra of compounds 1-3 are presented in Figures S1-S2, while the emission spectra of compounds 1-3 in the solid state and in deaerated acetonitrile solutions are shown in Figure 4. The emission maximum wavelengths $\left(\lambda_{\max }\right)$, lifetimes $\left(\tau_{\mathrm{em}}\right)$ and quantum yields $\left(\Phi_{\mathrm{em}}\right)$ are presented in Table 3. With the increase of the molecular mass of the cluster anion, the emission lifetimes and the quantum yields increase, while the emission maximum shifts in the blue region. Such enhancement of photoluminescence properties of octahedral molybdenum clusters was earlier observed for cluster complexes coordinated by residues of oxygenated acids [2, 23, 27, 39], and now this behaviour is also confirmed for compounds with non-oxygenated ligand $\mathrm{N}_{3}{ }^{-}$.

The powdered samples of 1-3 as well as acetonitrile solution of $\mathbf{1}$ exhibited double exponential emission decay, while the emission decay profiles of acetonitrile solutions of $\mathbf{2}$ and $\mathbf{3}$ were fitted by single exponential functions. The non-single exponential decays of hexamolybdenum cluster complexes in the solid phase are quite common and usually explained by the efficient excitation migration in a crystal and subsequent energy trapping/emission in the crystal defects. At the same time, the double exponential decay of chloride cluster complex (compound $\mathbf{1}$ ) in acetonitrile could be interpreted by its hydrolysis or replacement of terminal azide ligands by solvent molecules.

As it is typical for most known photoluminescent octahedral cluster complexes, the emission spectra of deaerated acetonitrile solutions of each cluster complex demonstrate significantly higher values of $\tau_{\mathrm{em}}$ and $\Phi_{\mathrm{em}}$ in comparison with those in aerated solutions (Table 3 ). This dependence is explained by the fact that the luminescence of such clusters that originates from a triplet excited state is quenching by oxygen dissolved in a solvent.[4-6, 40] Comparison of our data with those from $\mathrm{Na}_{2}\left[\left\{\mathrm{Mo}_{6} \mathrm{I}_{8}\right\}\left(\mathrm{N}_{3}\right)_{6}\right]$ [28] demonstrates the strong solvent effect on non-radiative relaxation of the triplet excited state. Specifically, $\left[\left\{\mathrm{Mo}_{6} \mathrm{I}_{8}\right\}\left(\mathrm{N}_{3}\right)_{6}\right]^{2-}$ in a deaerated acetonitrile solution was characterised by higher values of emission lifetime and quantum yield than those determined for the complex in an oxygen free aqueous solution.

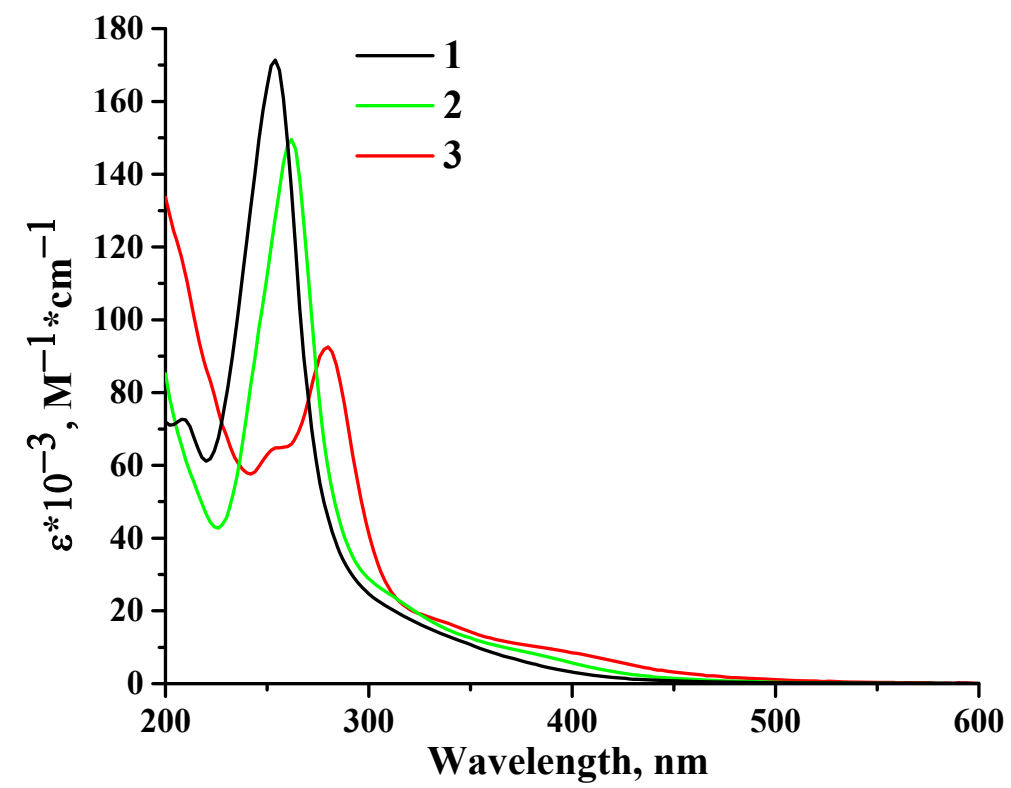

Figure 3. UV/Vis spectra of compounds 1-3 in acetonitrile. 

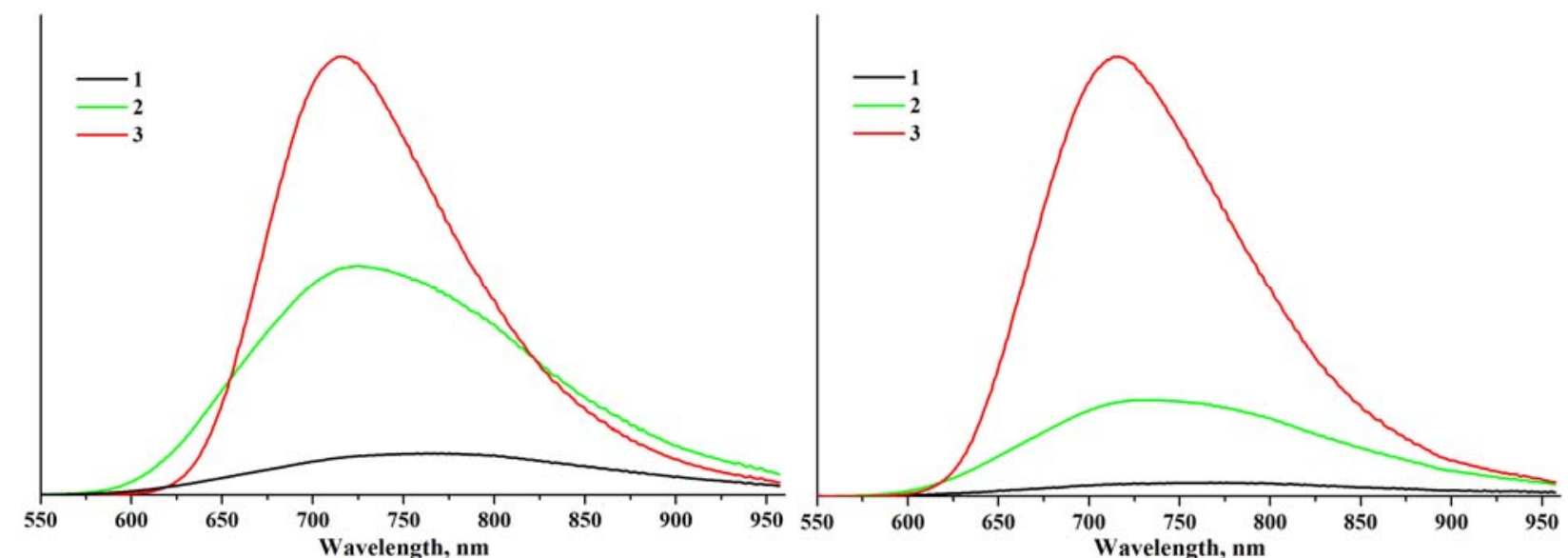

Figure 4. Emission spectra normalised on quantum yields of 1-3 in solid state (left) and deaerated acetonitrile solutions (right).

Table 3. Spectroscopic and photophysical parameters of cluster complexes 1-3 determined for powdered samples and both aerated (non-degassed) and deaerated $\mathrm{CH}_{3} \mathrm{CN}$ solutions as well as the data reported for a deaerated aqueous solution of $\mathrm{Na}_{2}\left[\left\{\mathrm{Mo}_{6} \mathrm{I}_{8}\right\}\left(\mathrm{N}_{3}\right)_{6}\right]$.

\begin{tabular}{|c|c|c|c|c|}
\hline \multicolumn{2}{|c|}{ Sample } & $\lambda_{\mathrm{em}} / \mathrm{nm}$ & $\tau_{\mathrm{em}} / \mu \mathrm{s}(\mathrm{A})$ & $\Phi_{\mathrm{em}}$ \\
\hline \multirow{3}{*}{ Solid } & 1 & 765 & $\begin{array}{l}\tau_{1}=27.3(0.34) \\
\tau_{2}=10.1(0.66)\end{array}$ & 0.02 \\
\hline & 2 & 725 & $\begin{aligned} \tau_{1} & =133(0.38) \\
\tau_{2} & =32.9(0.62)\end{aligned}$ & 0.11 \\
\hline & 3 & 716 & $\begin{array}{l}\tau_{1}=99.2(0.33) \\
\tau_{2}=26.7(0.67)\end{array}$ & 0.21 \\
\hline \multirow{3}{*}{ Acetonitrile solution } & 1 & 765 & $\begin{array}{c}\text { Aerated: } \\
\tau_{1}=7.8(0.15) \\
\tau_{2}=1.6(0.85) \\
\text { Deaerated: } \\
\tau_{1}=34.4(0.08) \\
\tau_{2}=2.6(0.92)\end{array}$ & $\begin{array}{c}\text { Aerated: } \\
<0.005 \\
\text { Deaerated } \\
\quad 0.01\end{array}$ \\
\hline & 2 & 735 & $\begin{array}{c}\text { Aerated solution: } \\
6.3 \\
\text { Deaerated: } \\
167\end{array}$ & $\begin{array}{c}\text { Aerated: } \\
<0.005 \\
\text { Deaerated } \\
0.07\end{array}$ \\
\hline & 3 & 716 & $\begin{array}{c}\text { Aerated: } \\
1.4 \\
\text { Deaerated: } \\
225\end{array}$ & $\begin{array}{c}\text { Aerated: } \\
<0.005 \\
\text { Deaerated } \\
0.32\end{array}$ \\
\hline $\begin{array}{l}\text { Aqueous solution } \\
\text { [28] }\end{array}$ & $\mathrm{Na}_{2}\left[\left\{\mathrm{Mo}_{6} \mathrm{I}_{8}\right\}\left(\mathrm{N}_{3}\right)_{6}\right]$ & 687 & 108 & 0.202 \\
\hline
\end{tabular}

\section{Cyclic voltammetry}

The electrochemical properties of compound $\mathbf{1 - 3}$ were studied by cyclic voltammetry (CV). CV curves are represented on Figure 3, while Table 3 summarises oxidation and reduction potentials. Our data show that the $\left[\left\{\mathrm{Mo}_{6} \mathrm{X}_{8}\right\}\left(\mathrm{N}_{3}\right)_{6}\right]^{2-}$ cluster complexes are oxidised irreversibly in the positive area, which is most likely associated with the destruction of the cluster core [41], and they are reduced reversibly in the negative area (Table 4, Figure 5). Interestingly, both reduction and oxidation potentials are only slightly dependent on the halogen within the cluster core. This is in 
contrast to the $\mathrm{CV}$ date reported for the related complexes of $\left[\left\{\mathrm{Mo}_{6} \mathrm{X}_{8}\right\} \mathrm{X}_{6}\right]^{2-}$ [42] and $\left[\left\{\mathrm{Mo}_{6} \mathrm{X}_{8}\right\} \mathrm{L} 6\right]^{2-}\left(\mathrm{X}=\mathrm{Cl}, \mathrm{Br}, \mathrm{I}\right.$ and $\mathrm{L}=\mathrm{PhSO}_{3}{ }^{-}, \mathrm{OTs}^{-}$or $\left.\mathrm{CF}_{3} \mathrm{COO}^{-}\right)[2,42]$, for which the oxidation potentials decrease in the row $\mathrm{Cl}>\mathrm{Br}>\mathrm{I}$. At the same time reduction potentials are close to those reported for $\left[\left\{\mathrm{Mo}_{6} \mathrm{X}_{8}\right\} \mathrm{X}_{6}\right]^{2-}$.[42] This observation suggests that the introduction of the donor ligand (azide) in the ligand environment affects significantly the electronic structure of HOMO orbital of the cluster complexes and thus the electron transfer in the oxidation process.

Table 4. Formal redox potentials $\left(\mathrm{E}_{1 / 2}\right)$ for complexes 1-3 in acetonitrile vs. saturated $\mathrm{AgCl} / \mathrm{Ag}$ couple. The scan rate was $0.5 \mathrm{~V} \cdot \mathrm{s}^{-1}$.

\begin{tabular}{|c|c|c|c|}
\hline \multirow{2}{*}{} & \multicolumn{3}{|c|}{$\mathrm{E}_{1 / 2}, \mathrm{~V}$} \\
\cline { 2 - 4 } & $\mathbf{1}$ & $\mathbf{2}$ & $\mathbf{3}$ \\
\hline$\left[\left\{\mathrm{Mo}_{6} \mathrm{X}_{8}\right\}\left(\mathrm{N}_{3}\right)_{6}\right]^{-/ 2-}$ & $1.74 *$ & $1.83^{*}$ & $1.89^{*}$ \\
\hline$\left[\left\{\mathrm{Mo}_{6} \mathrm{X}_{8}\right\}\left(\mathrm{N}_{3}\right)_{6}\right]^{2-/ 3-}$ & -1.38 & -1.30 & -1.29 \\
\hline
\end{tabular}

*The potential of irreversible oxidation.

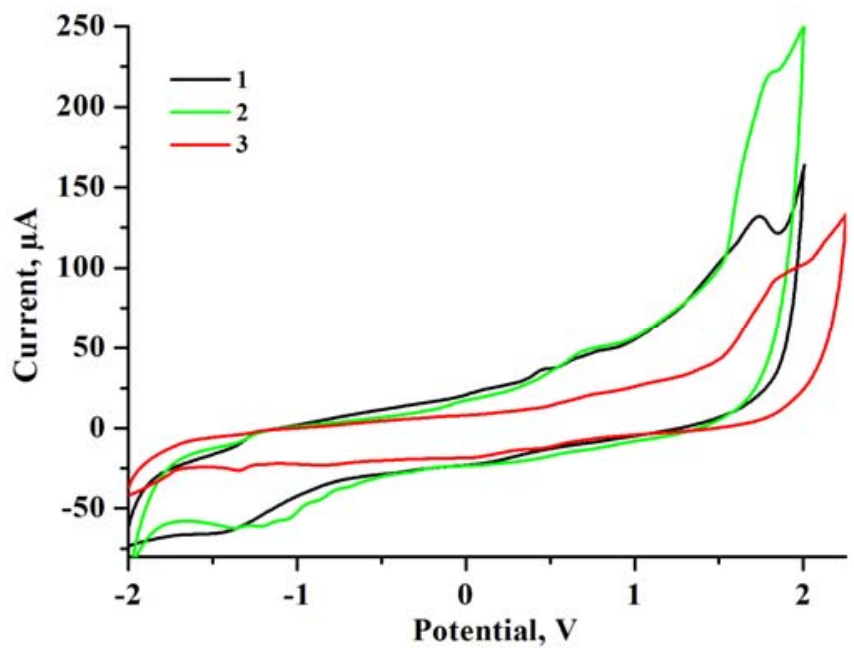

Figure 5. Cyclic voltammograms of compounds 1-3 $(1 \mathrm{mM})$ in acetonitrile vs. sat. $\mathrm{Ag} / \mathrm{AgCl}$. The scan rate was $0.5 \mathrm{~V} \cdot \mathrm{s}^{-1}$.

\section{Mass spectrometry}

The easy hydrolysis of different molybdenum cluster complexes was suggested or even evidenced in basic conditions earlier in several works $[8,28]$ with the final product of hydrolysis being aquahydroxo complex $\left[\left\{\mathrm{Mo}_{6} \mathrm{X}_{8}\right\}\left(\mathrm{H}_{2} \mathrm{O}\right)_{2}(\mathrm{OH})_{4}\right]$. In work [28] it was shown that dissolution of $\mathrm{Na}_{2}\left[\left\{\mathrm{Mo}_{6} \mathrm{I}_{8}\right\}\left(\mathrm{N}_{3}\right)_{6}\right]$ in water led to hydrolysis of the cluster complex with the formation of partially hydrolysed complex $\left[\left\{\mathrm{Mo}_{6} \mathrm{I}_{8}\right\}\left(\mathrm{N}_{3}\right)_{5}(\mathrm{OH})\right]^{2-}$, which is the first step towards fully hydrolysed aquahydroxo complex.

In this work, however, the formation of a different product of hydrolysis, namely $\left[\left(\left\{\mathrm{Mo}_{6} \mathrm{I}_{8}\right\}\left(\mathrm{N}_{3}\right)_{5}\right)_{2} \mathrm{O}\right]^{4-}$, was observed and structurally characterised within compound 4. This product can be considered as a result of condensation of two $\left[\left\{\mathrm{Mo}_{6} \mathrm{I}_{8}\right\}\left(\mathrm{N}_{3}\right)_{5}(\mathrm{OH})\right]^{2-}$ anions. To further confirm that $\mathbf{4}$ forms due to the hydrolysis of $\mathbf{3}$, the later was analysed by high-resolution electrospray mass spectrometry (ESI-MS). Namely, ESI-MS spectra were recorded for the solution of 3 in acetone, when it was fresh (Figure 6a) and after two weeks (Figure 6b). As one can see both spectra feature a set of isotopic pattern peaks with the maximum at 2085.95 that corresponds to ion $(\mathrm{Bu} 4 \mathrm{~N})\left[\left\{\mathrm{Mo}_{6} \mathrm{I}_{8}\right\}\left(\mathrm{N}_{3}\right)_{6}\right]^{-}$, while the mass spectrum of the same solution after two weeks had also an additional set of peaks with the maximum at 2051.44, which coincides with the $\mathrm{m} / \mathrm{z}$ value for dimeric dianion $\left({ }^{\mathrm{n}} \mathrm{Bu} 4 \mathrm{~N}\right)_{2}\left[\left(\left\{\mathrm{Mo}_{6} \mathrm{I}_{8}\right\}\left(\mathrm{N}_{3}\right)_{5}\right)_{2} \mathrm{O}\right]^{2-}$. Interestingly, no peaks corresponding to the $\left[\left\{\mathrm{Mo}_{6} \mathrm{I}_{8}\right\}\left(\mathrm{N}_{3}\right)_{5}(\mathrm{OH})\right]^{2-}$ ion (e.g. m/z 908.42 [28]) were observed. Presumably, the favourable 
formation of dimer $\left[\left(\left\{\mathrm{Mo}_{6} \mathrm{I}_{8}\right\}\left(\mathrm{N}_{3}\right)_{5}\right)_{2} \mathrm{O}\right]^{4-}$ instead of the parent ion $\left[\left\{\mathrm{Mo}_{6} \mathrm{I}_{8}\right\}\left(\mathrm{N}_{3}\right)_{5}(\mathrm{OH})\right]^{2-}$ described by Kirakci et al. [28] can be explained by the significant shift of the equilibrium towards the formation of the dimer due to the low amount of water in acetone solution.
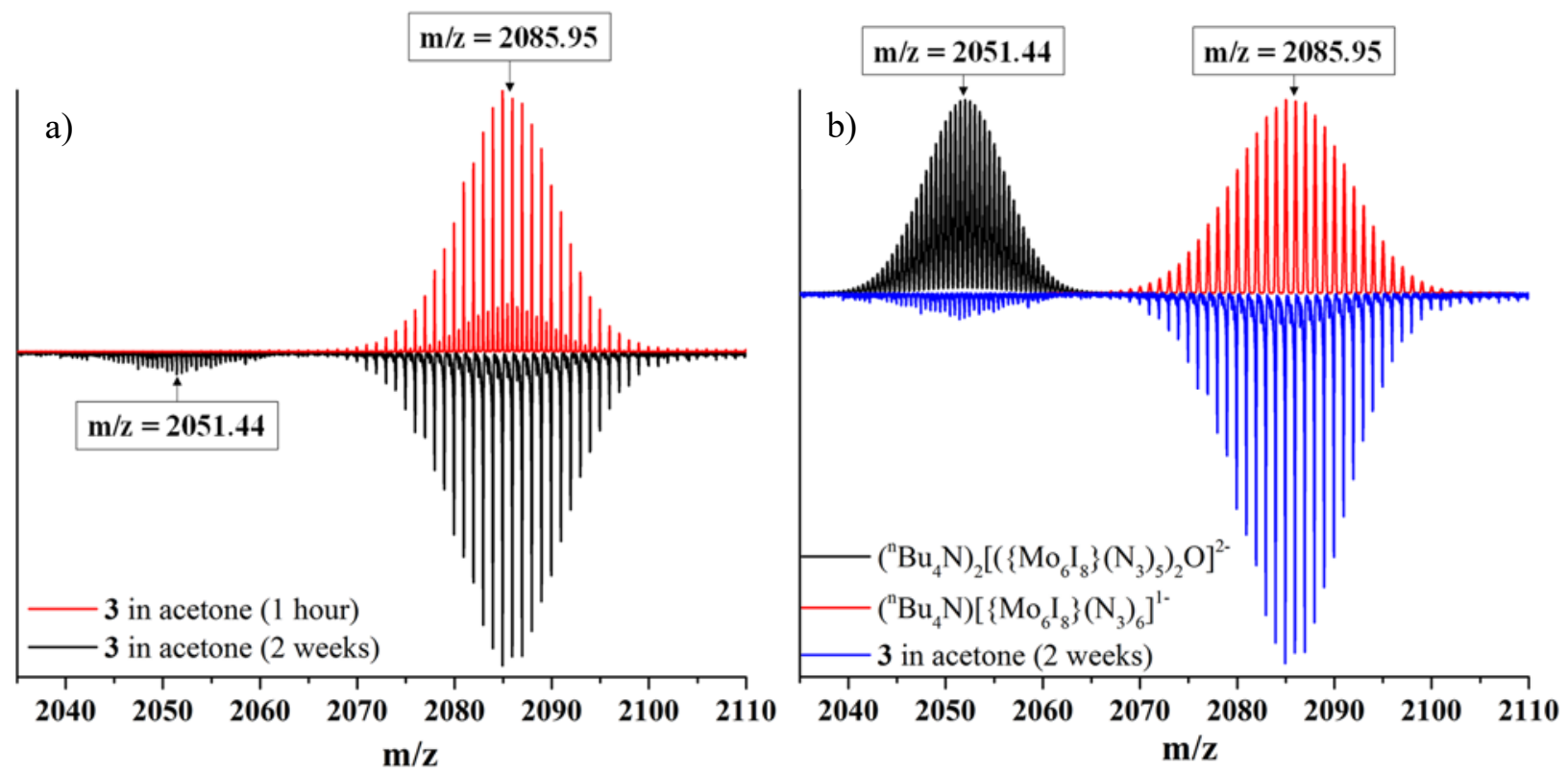

Figure 6. a) ESI-MS comparison of acetone solution of 3 after dissolution and after 2 weeks; b) ESI-MS of 3 after 2 weeks and simulation of cluster dimer.

\section{Conclusion}

This research demonstrates preparation and a crystal structure of $\left({ }^{n} \mathrm{Bu} 4 \mathrm{~N}\right)_{2}\left[\left\{\mathrm{Mog}_{6} \mathrm{I}_{8}\right\}\left(\mathrm{N}_{3}\right)_{6}\right]$ cluster complex as well as comparative study of the photophysical and electrochemical properties of the whole family of compounds $\left({ }^{\mathrm{n}} \mathrm{Bu} 4 \mathrm{~N}\right)_{2}\left[\left\{\mathrm{Mo}_{6} \mathrm{X}_{8}\right\}\left(\mathrm{N}_{3}\right)_{6}\right](\mathrm{X}=\mathrm{Cl}, \mathrm{Br}, \mathrm{I})$. Namely, it was shown that photoluminescence properties of $\left({ }^{\mathrm{n}} \mathrm{Bu} 4 \mathrm{~N}\right)_{2}\left[\left\{\mathrm{Mo}_{6} \mathrm{X}_{8}\right\}\left(\mathrm{N}_{3}\right)_{6}\right](\mathrm{X}=\mathrm{Cl}, \mathrm{Br}, \mathrm{I})$ follow the same trend, which was earlier found for the molybdenum octahedral cluster complexes coordinated by residues of oxygenated acids, i.e. in the row $\mathrm{Cl}-\mathrm{Br}-\mathrm{I}$ the luminescence quantum yield and the lifetime increase, while the emission maximum shifts slightly to the blue region. Current study thus confirms for the first time that this trend is also valid for non-oxygenated ligands. Moreover, our data in the context of other related works [2, 39, 42] suggest that luminescence quantum yields and lifetimes increase with the increase of the inner ligand (i.e. the halogen atomic number) and with the increase of electron withdrawing nature of the ligand.

Finally, this article also reports the direct evidence of the hydrolysis of $\left[\left\{\mathrm{Mo}_{6} \mathrm{I}_{8}\right\}\left(\mathrm{N}_{3}\right)_{6}\right]^{2-}$ with the formation of the dimeric anion $\left[\left(\left\{\mathrm{Mo}_{6} \mathrm{I}_{8}\right\}\left(\mathrm{N}_{3}\right)_{5}\right)_{2} \mathrm{O}\right]^{4-}$, which can be considered as a result of condensation of two ions $\left[\left\{\mathrm{Mo}_{6} \mathrm{I}_{8}\right\}\left(\mathrm{N}_{3}\right)_{5}(\mathrm{OH})\right]^{2-}$. Although we have not yet succeeded in the synthesis of $\left(\mathrm{Bu}_{4} \mathrm{~N}\right)_{4}\left[\left(\left\{\mathrm{Mo}_{6} \mathrm{I}_{8}\right\}\left(\mathrm{N}_{3}\right)_{5}\right)_{2} \mathrm{O}\right]$ as a pure compound, this study suggests that hydrolysis of molybdenum cluster complexes can result not only in substitution of the terminal ligands by $\mathrm{OH}^{-}$and $\mathrm{H}_{2} \mathrm{O}$ ligands, but, in water deficient conditions, also in condensation of the forming species with possible formation of oligomeric species in the analogy to poly-oxometalate compounds. The directed synthesis of such species may be interesting for the design of new photoluminescent, redox active or catalytic compounds and materials.

\section{Acknowledgements}


This work was supported by the Russian Science Foundation [grant number 15-15-10006]. Mass spectrometric experiments were performed with the financial support from FASO Russia [project 0333-2014-0001]. Also, Olga A. Efremova is grateful to the University of Hull for the academic starting grant, while Konstantin A. Brylev thanks the Japan Society for the Promotion of Science for a Post-Doctoral Fellowship for Foreign Researchers.

\section{Appendix A. Supplementary data}

CCDC 1510454-1510455 contain the supplementary crystallographic data for compounds 3 and 4. These data can be obtained free of charge via http://www.ccdc.cam.ac.uk/conts/retrieving.html, or from the Cambridge Crystallographic Data Centre, 12 Union Road, Cambridge CB2 1EZ, UK; fax: (+44) 1223336 033; or e-mail: deposit@ccdc.cam.ac.uk.

\section{References}

[1] M.A. Mikhailov, K.A. Brylev, P.A. Abramov, E. Sakuda, S. Akagi, A. Ito, N. Kitamura, M.N. Sokolov, Inorg. Chem. 55 (2016) pp. 8437-8445.

[2] O.A. Efremova, Y.A. Vorotnikov, K.A. Brylev, N.A. Vorotnikova, I.N. Novozhilov, N.V. Kuratieva, M.V. Edeleva, D.M. Benoit, N. Kitamura, Y.V. Mironov, S. M.A., A.J. Sutherland, Dalton Trans. 45 (2016) pp. 15427-15435.

[3] K. Kirakci, K. Fejfarova, M. Kucerakova, K. Lang, Eur. J. Inorg. Chem. (2014) pp. 2331-2336. [4] M.N. Sokolov, M.A. Mikhailov, K.A. Brylev, A.V. Virovets, C. Vicent, N.B. Kompankov, N. Kitamura, V.P. Fedin, Inorg. Chem. 52 (2013) pp. 12477-12481.

[5] K. Kirakci, P. Kubat, M. Dusek, K. Fejfarova, V. Sicha, J. Mosinger, K. Lang, Eur. J. Inorg. Chem. 19 (2012) pp. 3107-3111.

[6] M.N. Sokolov, M.A. Mihailov, E.V. Peresypkina, K.A. Brylev, N. Kitamura, V.P. Fedin, Dalton Trans. 40 (2011) pp. 6375-6377.

[7] A.M. Cheplakova, A.O. Solovieva, T.N. Pozmogova, Y.A. Vorotnikov, K.A. Brylev, N.A. Vorotnikova, E.V. Vorontsova, Y.V. Mironov, A.F. Poveshchenko, K.A. Kovalenko, M.A. Shestopalov, J. Inorg. Biochem. 166 (2017) pp. 100-107.

[8] Y.A. Vorotnikov, O.A. Efremova, N.A. Vorotnikova, K.A. Brylev, M.V. Edeleva, A.R. Tsygankova, A.I. Smolentsev, N. Kitamura, Y.V. Mironov, M.A. Shestopalov, Rsc Adv. 6 (2016) pp. 43367-43375.

[9] A. Beltran, M. Mikhailov, M.N. Sokolov, V. Perez-Laguna, A. Rezusta, M.J. Revillo, F. Galindo, J. Mater. Chem. B. 4 (2016) pp. 5975-5979.

[10] S.K. Nayak, M. Amela-Cortes, C. Roiland, S. Cordier, Y. Molard, Chem. Commun. 51 (2015) pp. 3774-3777.

[11] D.E.J.G.J. Dolmans, D. Fukumura, R.K. Jain, Nat. Rev. Cancer. 3 (2003) pp. 380-387.

[12] A.O. Solovieva, Y.A. Vorotnikov, K.E. Trifonova, O.A. Efremova, A.A. Krasilnikova, K.A. Brylev, E.V. Vorontsova, P.A. Avrorov, L.V. Shestopalova, A.F. Poveshchenko, Y.V. Mironov, M.A. Shestopalov, J. Mater. Chem. B. 4 (2016) pp. 4839-4846.

[13] C. Neaime, M. Amela-Cortes, F. Grasset, Y. Molard, S. Cordier, D. Benjamin, M. Mortier, T. Takei, K. Takahashi, H. Haneda, M. Verelst, S. Lechevallier, Phys. Chem. Chem. Phys. 18 (2016) pp. 30166-30173.

[14] S. Cordier, F. Dorson, F. Grasset, Y. Molard, B. Fabre, H. Haneda, T. Sasaki, M. Mortier, S. Ababou-Girard, C. Perrin, J. Cluster Sci. 20 (2009) pp. 9-21.

[15] S. Cordier, F. Grasset, Y. Molard, M. Amela-Cortes, R. Boukherroub, S. Ravaine, M. Mortier, N. Ohashi, N. Saito, H. Haneda, J. Inorg. Organomet. Polym. Mater. 25 (2015) pp. 189-204.

[16] A.A. Krasilnikova, A.O. Solovieva, K.E. Trifonova, K.A. Brylev, A.A. Ivanov, S.-J. Kim, M.A. Shestopalov, M.S. Fufaeva, A.M. Shestopalov, Y.V. Mironov, A.F. Poveshchenko, L.V. Shestopalova, (2016) DOI:10.1002/cmmi.1707.

[17] A.A. Krasilnikova, M.A. Shestopalov, K.A. Brylev, I.A. Kirilova, O.P. Khripko, K.E. Zubareva, Y.I. Khripko, V.T. Podorognaya, L.V. Shestopalova, V.E. Fedorov, Y.V. Mironov, J. Inorg. Biochem. 144 (2015) pp. 13-17. 
[18] M.A. Shestopalov, K.E. Zubareva, O.P. Khripko, Y.I. Khripko, A.O. Solovieva, N.V. Kuratieva, Y.V. Mironov, N. Kitamura, V.E. Fedorov, K.A. Brylev, Inorg. Chem. 53 (2014) pp. 9006-9013.

[19] A.A. Krasilnikova, A.O. Solovieva, A.A. Ivanov, K.E. Trifonova, T.N. Pozmogova, A.R. Tsygankova, A.I. Smolentsev, E.I. Kretov, D.S. Sergeevichev, M.A. Shestopalov, Y.V. Mironov, A.M. Shestopalov, A.F. Poveshchenko, L.V. Shestopalova, Nanomedicine: NBM. (2016) DOI:10.1016/j.nano.2016.1010.1016.

[20] S. Cordier, Y. Molard, K.A. Brylev, Y.V. Mironov, F. Grasset, B. Fabre, N.G. Naumov, J. Clust. Sci. 26 (2015) pp. 53-81.

[21] T. Aubert, F. Cabello-Hurtado, M.A. Esnault, C. Neaime, D. Lebret-Chauvel, S. Jeanne, P. Pellen, C. Roiland, L. Le Polles, N. Saito, K. Kimoto, H. Haneda, N. Ohashi, F. Grasset, S. Cordier, J. Phys. Chem. C. 117 (2013) pp. 20154-20163.

[22] F. Grasset, F. Dorson, Y. Molard, S. Cordier, V. Demange, C. Perrin, V. Marchi-Artzner, H. Haneda, Chem. Commun. (2008) pp. 4729-4731.

[23] N.A. Vorotnikova, O.A. Efremova, A.R. Tsygankova, K.A. Brylev, M.V. Edeleva, O.G. Kurskaya, A.J. Sutherland, A.M. Shestopalov, Y.V. Mironov, M.A. Shestopalov, Polym. Adv. Technol. 27 (2016) pp. 922-928.

[24] O.A. Efremova, K.A. Brylev, Y.A. Vorotnikov, L. Vejsadova, M.A. Shestopalov, G.F. Chimonides, P. Mikes, P.D. Topham, S.J. Kim, N. Kitamura, A.J. Sutherland, J. Mater. Chem. C. 4 (2016) pp. 497-503.

[25] M. Amela-Cortes, Y. Molard, S. Paofai, A. Desert, J.L. Duvail, N.G. Naumov, S. Cordier, Dalton Trans. 45 (2016) pp. 237-245.

[26] M. Amela-Cortes, S. Paofai, S. Cordier, H. Folliot, Y. Molard, Chemical Comm. 51 (2015) pp. 8177-8180.

[27] O.A. Efremova, M.A. Shestopalov, N.A. Chirtsova, A.I. Smolentsev, Y.V. Mironov, N. Kitamura, K.A. Brylev, A.J. Sutherland, Dalton Trans. 43 (2014) pp. 6021-6025.

[28] K. Kirakci, P. Kubat, M. Kucerakova, V. Sicha, H. Gbelcova, P. Lovecka, P. Grznarova, T. Ruml, K. Lang, Inorg. Chim. Acta. 441 (2016) pp. 42-49.

[29] S.A. Knott, J.N. Templeton, J.L. Durham, A.M. Howard, R. McDonald, L.F. Szczepura, Dalton Trans. 42 (2013) pp. 8132-8139.

[30] A. Barras, M.R. Das, R.R. Devarapalli, M.V. Shelke, S. Cordier, S. Szunerits, R. Boukherroub, Appl. Catal. B-Environ. 130 (2013) pp. 270-276.

[31] A. Barras, S. Cordier, R. Boukherroub, Appl. Catal. B-Environ. 123 (2012) pp. 1-8.

[32] D. Bublitz, W. Preetz, M.K. Simsek, Z. Anorg. Allg. Chem. 623 (1997) pp. 1-7.

[33] Bruker, APEX2 (Version 1.08), SAINT (Version 7.03), SADABS (Version 2.11), SHELXTL(Version 6.12), Bruker AXS Inc., Madison, WI, USA, 2004. pp.

[34] A. Gandubert, K.A. Brylev, T.T. Nguyen, N.G. Naumov, N. Kitamura, Y. Molard, R. Gautier, S. Cordier, Z. Anorg. Allg. Chem. 639 (2013) pp. 1756-1762.

[35] G. Pilet, S. Cordier, S. Golhen, C. Perrin, L. Ouahab, A. Perrin, Solid State Sci. 5 (2003) pp. 1263-1270.

[36] F. Simon, K. Boubekeur, J.C.P. Gabriel, P. Batail, Chem. Comm. (1998) pp. 845-846.

[37] M.B. Pereira, C.R. Kopp, L.A. Fontana, G.M. de Oliveira, D.F. Back, P.C. Piquini, M.A. Villetti, New J. Chem. 38 (2014) pp. 3092-3101.

[38] J. Colin, B. Chevrier, A. Decian, R. Weiss, Angew. Chem. Int. Ed. 22 (1983) pp. 247-248.

[39] M.A. Mikhailov, K.A. Brylev, A.V. Virovets, M.A. Gallyamov, I.N. Novozhilov, M.N. Sokolov, New J. Chem. 40 (2016) pp. 1162-1168.

[40] J.A. Jackson, C. Turro, M.D. Newsham, D.G. Nocera, J. Phys. Chem. 94 (1990) pp. $4500-$ 4507.

[41] B. Fabre, S. Cordier, Y. Molard, C. Perrin, S. Ababou-Girard, C. Godet, J. Phys. Chem. C. 113 (2009) pp. 17437-17446.

[42] K. Kirakci, P. Kubat, J. Langmaier, T. Polivka, M. Fuciman, K. Fejfarova, K. Lang, Dalton Trans. 42 (2013) pp. 7224-7232. 
